\title{
Activated Charcoal for Acute Poisoning: One Toxicologist's Journey
}

\author{
Kent R. Olson
}

Published online: 20 May 2010

(C) The Author(s) 2010. This article is published with open access at Springerlink.com

Keywords Activated charcoal $\cdot$ Gastrointestinal decontamination $\cdot$ Poisoning $\cdot$ Drug overdose

When I began studying clinical toxicology in 1981, the issue of gastrointestinal decontamination after acute ingestion seemed pretty well settled: "universal antidote," apomorphine and salt-water emesis were no longer used $[1,2]$; and I was taught that barring a specific contraindication, the awake patient was given syrup of ipecac to induce emesis, and the drowsy or uncooperative patient was lavaged [3]. After gastric emptying, everyone received activated charcoal (AC). The only controversy seemed to be over whether one should add a cathartic to speed gastrointestinal transit [4].

Within a few years, my comfortable assumptions were upset by several prospective randomized trials that cast doubt on the value of gastric emptying prior to AC [5-8]. Merigian even challenged the ritual of routine oral AC when he assigned a subgroup of asymptomatic overdose patients to observation without charcoal and found no difference in outcome [8]. At about the same time, case reports of adverse outcomes in patients given AC began to appear [9-12]. (Ironically, when reviewing the literature in preparation for the present article, I found skepticism about gastrointestinal decontamination dating back to the 1940s.

Project not funded by any external sources

Not previously presented at any meeting

K. R. Olson $(\bowtie)$

California Poison Control System, San Francisco Division,

University of California, San Francisco,

UCSF Box 1369, San Francisco, CA 94143-1369, USA

e-mail: olson@calpoison.org
As summarized by Matthew [13], Harstad and Danish colleagues reported in 1942 that relatively little phenobarbital was recovered by lavage even shortly after overdose [14] and this, along with their finding of particles of charcoal in the lungs of patients who died, led them to call for the abandonment of gastric lavage for poisoning.)

In recent years, my colleagues and I have continued to debate the value of various methods of gastric decontamination and the role and risks of activated charcoal, and it is clear to me that the issue remains muddy. Some have taken a firm stand that no treatment should be recommended that is not supported by evidence from a randomized controlled trial (RCT). Position statements published jointly by the American Academy of Clinical Toxicology and the European Association of Poison Centres and Clinical Toxicologists have adopted a generally conservative view (i.e., lacking evidence, these procedures should not be used routinely) [15-18]. Others have argued that quality RCTs are few and flawed and that we may never have all the evidence we need to guide management of every case. A number of thorough and thoughtful reviews and editorials have summarized the literature and have attempted to provide guidance for the selected use of gastric emptying or activated charcoal [19-23].

In this brief review, I will attempt to answer the following questions about activated charcoal: what is it and what does it bind to? What do animal studies and human volunteer studies reveal about its efficacy in simulated overdose? What evidence is there from case reports and controlled trials for its benefit in humans? What are the potential risks of administering activated charcoal? And finally, how can we put our knowledge about charcoal to use in managing specific patients? 


\section{What is Activated Charcoal and What Does it Bind?}

The reader wanting a comprehensive and yet very readable review of the origins of activated charcoal, its physiochemical properties, as well as data on adsorption of various drugs and poisons, and reported animal and human studies is directed to Activated Charcoal in Medical Applications, by David O. Cooney [24]. This excellent book traces the use of charcoal for medicinal purposes dating as far back as $1550 \mathrm{BC}$ and reviews scientific and clinical studies of charcoal from the eighteenth century to the present.

Charcoal is produced by heating pulverized carbonaceous substances such as sawdust, peat, or coconut shells to very high temperatures $\left(600-900^{\circ} \mathrm{C}\right)$ followed by "activation" using steam or hot air to erode the internal surfaces of the product and thereby increase its adsorptive surface area. Typical surface areas for activated charcoals average of $800-1,200 \mathrm{~m}^{2} / \mathrm{g}$ [25]. Thus, a 50-g dose of activated charcoal has an adsorptive surface area equivalent to about seven football fields! "Superactivated" charcoals may have a surface area of 2,800-3,500 m² $/ \mathrm{g}$ and can adsorb greater quantities of drug [26].

Adsorption results from weak intermolecular (Van der Waals) forces and desorption of the solute can occur if sufficient charcoal is not given. Ionization and polarity are important factors in determining adsorption. Strongly dissociated salts such as sodium chloride or potassium nitrate are not well adsorbed, while nondissociating solutes such as mercuric chloride and iodine are adsorbed very well [27]. Organic compounds are generally well adsorbed and large poorly water-soluble compounds (e.g., fatty acids) are better adsorbed to AC than smaller compounds with polar substituent groups (e.g., alcohols). As pH may affect ionization, it is not surprising that salicylate is more completely adsorbed at a low $\mathrm{pH}$, when more of the drug is in a nonionized state. The opposite is true for a basic compound such as aniline [28]. In vitro, the maximal binding capacity of $\mathrm{AC}$ for drugs and poisons varies from $35 \mathrm{mg} / \mathrm{g}$ AC for potassium cyanide to a whopping $1,800 \mathrm{mg} / \mathrm{g}$ of $\mathrm{AC}$ for mercuric chloride [29]. A number of common hypnotic and sedative drugs had maximal binding in the range of $56-262 \mathrm{mg} / \mathrm{g}$ of $\mathrm{AC}$ depending on the drug, the $\mathrm{pH}$, and the dose of $\mathrm{AC}$ [30]. The conventionally accepted optimal ratio of approximately 10:1 (dose of AC/amount of drug ingested by weight) is based on these and other studies [31], but it is worth noting that more or less AC may be required depending on the specific poison. A recent meta-analysis of human volunteer studies suggests that the optimal ratio of activated charcoal to drug may be closer to $40: 1$ [32].

Activated charcoal does not effectively adsorb ferrous sulfate [33] or lithium carbonate [34]. Despite the famous claim that in 1811 Bertrand publicly swallowed a lethal dose of arsenic trioxide mixed with charcoal [35], more recent studies appear to disprove its effectiveness for this poison [36]. Studies on ethanol and other alcohols also report poor adsorption, which is not surprising because these are small highly water-soluble molecules [37]. However, another possible explanation is that at usual toxic doses (e.g., more than $25 \mathrm{~mL}$ ) there is little chance of achieving a 10:1 ratio by weight of $\mathrm{AC}$ to drug. This argument is supported by an in vitro study in which $5 \mathrm{~g} \mathrm{AC}$ was mixed with simulated gastric fluid and varying amounts of methanol or ethylene glycol [38]. While charcoal was no match for $100-\mathrm{mL}$ doses of the solvents (only $26 \%$ of methanol and $2 \%$ of ethylene glycol was adsorbed), it adsorbed most of $1-\mathrm{mL}$ dose $(59 \%$ methanol and $68 \%$ of ethylene glycol adsorbed). The 1-mL dose corresponds to about a 5:1 ratio of $\mathrm{AC} /$ solvent by weight. So maybe it is really a matter of not enough charcoal.

\section{Animal Studies}

A large number of in vivo studies have been carried out in animals and are well summarized by Cooney [39]. (Further discussion of these and more recent animal studies is beyond the scope of this review.) The results vary depending on the drug, the amount of drug given, the amount of charcoal used, and the time delay to administration of AC. Cooney writes, "With almost any substance, if enough charcoal is given without undue delay, the charcoal will be reasonably effective in reducing the absorption of that substance."

\section{Human Volunteer Studies}

Human volunteer studies involving oral activated charcoal have been well summarized by previous authors [16, 21]; I will highlight a few of them. Curtis gave adult volunteers 24 81-mg aspirin tablets followed $1 \mathrm{~h}$ later by $60 \mathrm{~g} \mathrm{AC}$ in magnesium sulfate; compared with controls, the charcoal reduced total salicylate absorption by $43.6 \%$ [40]. Tenenbein reported a $57 \%$ reduction in drug absorption by giving $50 \mathrm{~g}$ $\mathrm{AC} 1 \mathrm{~h}$ after a 5-g dose of ampicillin in volunteers [41]. In another study, $50 \mathrm{~g}$ of $\mathrm{AC}$ reduced the area under the curve (AUC) for acetaminophen absorption by $56 \%$ if given $1 \mathrm{~h}$ after a 3-g dose of the drug, but only $22 \%$ if the $\mathrm{AC}$ was given after $2 \mathrm{~h}$ [42]. In a similar study, Green [43] reported reductions in AUC after a 4-g acetaminophen ingestion of $30.5 \%$ and $7.7 \%$ by administration of $50 \mathrm{~g} \mathrm{AC}$ after 1 or $2 \mathrm{~h}$, respectively. Bond [21] combined the results of numerous studies into a graph that illustrates the importance of time to treatment with AC (see Fig. 1).

Treatment with $\mathrm{AC}$ more than $1 \mathrm{~h}$ after ingestion might be more effective if the drug ingested has pharmacologic 
Reduction in absorption (\%)

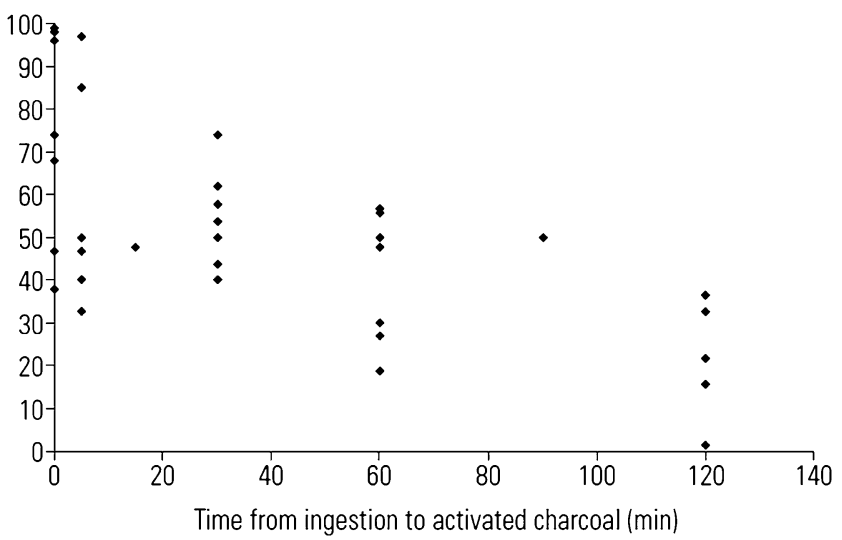

Fig. 1 Impact of the time to activated charcoal administration on reduction in drug absorption (reproduced from Bond, with permission [21])

effects that delay its delivery to the small intestine, where most absorption occurs (e.g., aspirin, anticholinergic drugs, opioids), or is contained in a modified-release preparation that is designed to slow its absorption. To test this premise, Green administered atropine $0.01 \mathrm{mg} / \mathrm{kg}$ IM $15 \mathrm{~min}$ prior to $3.9 \mathrm{~g}$ acetaminophen to a group of volunteers and measured a $47 \%$ reduction in AUC when charcoal was given after $1 \mathrm{~h}$ compared to a $20 \%$ reduction in AUC for volunteers who received charcoal but no atropine [44]. Mullins reported a $43 \%$ reduction in the AUC of acetaminophen combined with oxycodone if charcoal was given at $1 \mathrm{~h}$ compared with a $22 \%$ and $15 \%$ reduction after 2 and $3 \mathrm{~h}$, respectively [45]. More impressive results were obtained for modified-release drugs: AC given $4 \mathrm{~h}$ after ingestion of nine $325-\mathrm{mg}$ entericcoated aspirin tablets reduced the AUC by $57 \%$ [46], and $\mathrm{AC}$ given at 2 and $4 \mathrm{~h}$ after ingestion of $240 \mathrm{mg}$ of sustained-release verapamil reduced the AUC by $35 \%$ and $32 \%$, respectively [47]. Minton reported a $63.3 \%$ reduction in drug absorption from three 200-mg sustained-release theophylline tablets when charcoal plus sorbitol was delayed for $6 \mathrm{~h}$ [48].

Jurgens performed a meta-analysis of 64 controlled human volunteer studies, which confirmed the benefit of $\mathrm{AC}$ when given 0-5 min after drug ingestion (median reduction in drug absorption $88.4 \% ; 25-75$ percentile $=65$ $96.8 \%, P<0.00001)$ and also showed that the effect of AC continued to be statistically significant when AC was administered $1 \mathrm{~h}$ after drug intake (median reduction $38.4 \%$; 25-75 percentile $=25.4-61.7 \%, P<0.00001), 2 \mathrm{~h}$ after drug ingestion (median reduction $24.4 \% ; 25-75$ percentile $=13.6$ $31.5 \%, P<0.00001$ ), and even up to $4 \mathrm{~h}$ after drug intake (median reduction $27.4 \% ; 25-75$ percentile $=21.3-31.5 \%$, $P=0.0006$ ) [32]. The authors pointed out that in one quarter of the comparisons, a 1-h delay to AC still reduced drug uptake by nearly $62 \%$ and in a quarter of the comparisons, a 4-h delay to AC still reduced drug uptake by over $31 \%$. A very interesting feature of their study was an analysis of the reduction in drug absorption plotted against the $\mathrm{AC} /$ drug ratio, which suggested that the optimal dose of $\mathrm{AC}$ may be much greater than the conventional 10:1 ratio (see Fig. 2). Another intriguing finding was that the reduction in drug exposure by $\mathrm{AC}$ was correlated with the drug's volume of distribution (Vd). This is not really surprising since drugs with a large $\mathrm{Vd}$ tend to be nonpolar and poorly water soluble, physiochemical characteristics that are likely to increase a compound's adsorptive binding to charcoal [27].

\section{Clinical Studies of Activated Charcoal in Patients with Drug Overdose}

Three of the large, prospective RCTs of gastric emptying in acute poisoning that cast doubt on the use of ipecacinduced emesis or gastric lavage were not designed to assess the utility of activated charcoal [5-7]. However, another early RCT involving 808 drug overdose patients randomized a subgroup of 451 asymptomatic patients to receive oral activated charcoal or supportive care only [8]. No patients showed clinical deterioration in either group. Obviously, this was a very-low-risk group to begin with.

What about potentially toxic ingestions? The literature is conflicting. Two studies measured drug levels in patients with tricyclic antidepressant overdose and found no difference between those who received activated charcoal and those who did not $[49,50]$. However, in both of these studies, patients were first treated with gastric lavage, which undoubtedly delayed the time to AC administration and probably forced drug into the small intestine further out of the reach of charcoal.

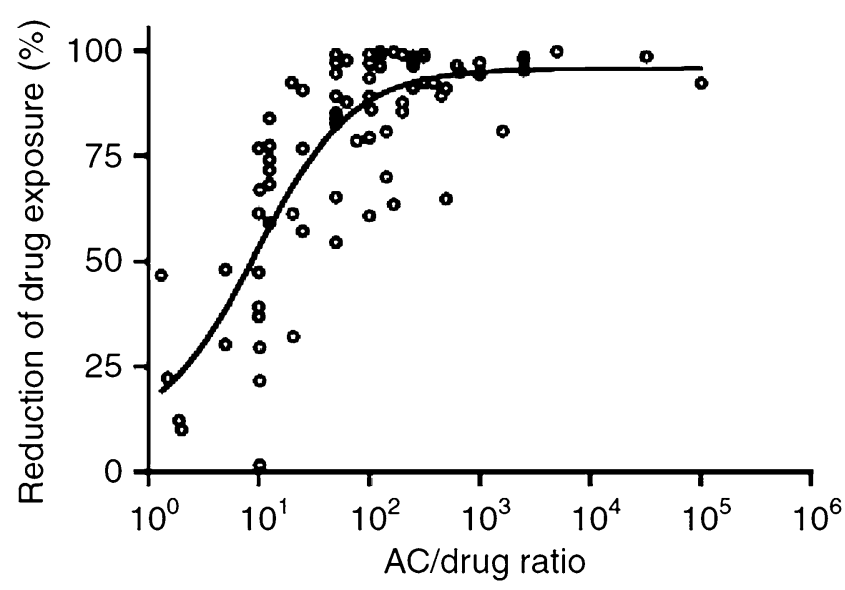

Fig. 2 Effectiveness of activated charcoal as a function of the $\mathrm{AC} /$ drug ratio (reproduced from Jurgens et al., with permission [32]) 
Underhill randomly assigned patients with acute acetaminophen overdose of $5 \mathrm{~g}$ or more, and who arrived for treatment within $4 \mathrm{~h}$ (median time of arrival, $123 \mathrm{~min}$ ), to one of four groups: gastric lavage, oral activated charcoal in a 10:1 ratio, syrup of ipecac, and no treatment (controls) [51]. Patients in the charcoal group had the greatest fall in serum acetaminophen levels. The control group was abandoned for ethical reasons after serum acetaminophen levels increased in four out of five patients. In a retrospective review of 981 acetaminophen overdoses treated over a 10-year period, patients who had received activated charcoal were significantly less likely to have toxic acetaminophen levels [52]. A prospective observational multi-center study of patients with acetaminophen overdose whose treatment was initiated $4 \mathrm{~h}$ or later after ingestion found a reduced (but not statistically significant) incidence of hepatotoxicity (AST or ALT $>1,000)$ in the group that received activated charcoal plus N-acetylcysteine (NAC) compared with those that received only NAC $(0 / 40$ in the charcoal group versus $2 / 17$ in controls; $P=0.08$ ) [53]. The two groups did not differ in time to initiating NAC therapy. A larger retrospective analysis of reports to the American Association of Poison Control Centers' Toxic Exposure Surveillance System (TESS) also found a reduced likelihood of hepatotoxicity in patients who received both $\mathrm{AC}$ and NAC compared with NAC alone, but these data did not record when NAC treatment was initiated [54]. If patients arriving later and therefore at greater risk were judged to be "too late" to receive charcoal this could have skewed the results in favor of AC.

Isbister and colleagues employed a complex Bayesian analysis method using retrospective data collected from a total of more than 500 patients with citalopram overdose and found that administration of $\mathrm{AC}$ reduced the probability of having a prolonged QT interval [55, 56]. The same group used Bayesian methodology and retrospective concentration-time data to show that administration of $\mathrm{AC}$ resulted in a significant reduction in drug absorption after overdose by citalopram (22\% reduction in bioavailability) and quetiapine (35\% reduction) [57, 58]. Activated charcoal was initiated after $1 \mathrm{~h}$ in most of their patients. Recently, they showed that a combination of $\mathrm{AC}$ and whole bowel irrigation reduced by $29 \%$ the amount of drug absorbed and also reduced the peak drug level after overdoses of venlafaxine [59]. Most of the venlafaxine patients had taken a sustained-release preparation.

Roberts analyzed cardenolide pharmacokinetics in patients with acute self-poisoning by ingestion of yellow oleander (Thevetia peruviana) seeds and found a significant reduction in the apparent terminal half-life in patients who received activated charcoal $(33.9 \mathrm{~h})$ compared to those who did not (62.9 h) [60]. However, clinical outcome (mortality) studies of activated charcoal for yellow oleander seed poisoning have produced conflicting results $[61,62]$.
In addition to the controlled trial of $\mathrm{AC}$ in a subgroup of asymptomatic overdose patients described earlier [8], three other large prospective outcome studies comparing $\mathrm{AC}$ with supportive care are worth mentioning. Merigian found no difference in outcome for 1,479 overdose patients randomized to orally receive AC or supportive care only [63]. The vast majority of cases $(1,266$ patients) were not admitted to the hospital, reflecting the low risk of serious outcome in most overdoses presenting to the emergency department (ED). Lopsided numbers in the charcoal (399 patients) and no charcoal (1,080 patients) group raises questions about the randomization method (even-odd day allocation).

Cooper randomized 327 patients with acute drug overdose using a sealed envelope method and found no differences between $\mathrm{AC}$ and supportive care only groups with respect to length of stay, intensive care unit (ICU) admission, or mortality [64]. However, most patients were not very ill (they excluded seven patients with ingestions judged to be too serious to enter a randomized trial), and there was only one death (in the no treatment group).

The largest RCT to date was reported last year by Eddleston and colleagues in The Lancet [62]. They randomized 4,632 Sri Lankan patients with acute intentional self-poisoning (mostly pesticides and yellow oleander seeds) to receive a single $50 \mathrm{~g}$ dose of AC, multiple doses of $\mathrm{AC}$ (six doses of $50 \mathrm{~g}$ every $4 \mathrm{~h}$ ), or supportive care only. They found no difference in mortality (their primary outcome measure) between the three groups. The study was carried out in secondary receiving hospitals in rural Sri Lanka where transport time to medical care is often lengthy. Indeed, patients in the three groups arrived at the hospital an average of $4.2,4.2$, and $4.3 \mathrm{~h}$ after the ingestion, respectively, which might explain the absence of benefit from AC. The authors reported that they could not demonstrate an advantage to charcoal use in a subgroup of patients who presented earlier. However, only 176 patients arrived within 60 min and only 664 within $2 \mathrm{~h}$, and the study was not powered to detect a difference in mortality at these numbers. Moreover, it is not clear how soon after arrival patients were randomized and received their first dose of AC. The authors constructed a Forest plot of outcomes comparing any use of $\mathrm{AC}$ versus no use of $\mathrm{AC}$ in 30-min subgroups and found no significant differences; however, the subgroups were small. Using data reported by the authors, for patients arriving within 90 min of ingestion, I calculated a reduced odds ratio for death (0.77) if any charcoal was given, but with a $95 \%$ confidence of $0.35-1.70$.

It remains to be seen what impact this latest study will have on the use of activated charcoal for poisonings. Clearly, conditions are different in the rural developing world. The patient may have to walk or be taken by bicycle or tractor to a local dispensary, where first aid of variable quality and consistency may be administered. In many 
cases, family or friends may insist that the patient undergo forced emesis or gastric lavage with large quantities of water without airway protection, even in unconscious patients [65]. To get to a referral hospital may require a few hours' drive in a private vehicle or a basic ambulance lacking advanced life-support capabilities. Thus, in Eddleston's patients, a delay to initiation of activated charcoal might also be viewed as a delay to intensive supportive care and the patient's fate may have already been determined before enrollment in the study.

\section{What are the Risks of Giving Activated Charcoal?}

Although charcoal is generally considered a benign treatment, there are some risks with its use. Many patients vomit and a few of them aspirate gastric contents into the lungs causing a pneumonitis. Compliance is unpredictable, and complications may occur when passing a nasogastric tube to administer the charcoal. Addition of a cathartic may cause diarrhea and failure to give a laxative may cause constipation or the formation of charcoal briquettes in the intestinal tract [66]. Charcoal has been blamed for appendicitis [67] and intestinal perforation [68] in single case reports.

While most adolescents and adults will drink activated charcoal voluntarily, the data regarding compliance in children is inconclusive. Two studies found a high acceptance rate (83-90\%) in children offered AC [69, 70]. In contrast, Kornberg reported that only $21 / 70(30 \%)$ of children in the ED with an ingestion voluntarily took oral charcoal; the rest received it by nasogastric tube [71]. House staff and nurses were instructed to try and get the child to take the AC willingly, but the authors acknowledged that most of the ED staff believed that children were unlikely to do so and may not have tried very hard. Another factor in Kornberg's study is that nearly half the children had received syrup of ipecac and may have been unwilling or unable to tolerate oral charcoal. Another ED study found that only $44 \%$ of children under 6 years old drank AC willingly [72]. Adding a flavoring agent did not appear to influence compliance in these children. Various "taste-test" studies have provided conflicting data about the preferences of children for AC mixed in chocolate milk, cola, cherry syrup, orange juice, or ice cream [73-75]. One pediatric toxicologist advised me that in his experience the most reliable way to get a child to drink charcoal was to walk into the room with a big smile and say, "Drink it -- or I'll give you a shot!!" (personal communication 2002). Personally, I have not found any of these or other touted methods fool proof.

Vomiting is the most common complication of $\mathrm{AC}$ administration. Rates of vomiting in adults range from $7 \%$ [76] to $12.5 \%$ [77] to $23 \%$ [63] and in children from $6.9 \%$
[70] to $16 \%$ [71] to $20.4 \%$ [78]. Not surprisingly, if syrup of ipecac preceded the charcoal, the rate of vomiting was even higher: Kornberg reported that $18 / 32$ children who had received ipecac vomited after charcoal [71]. Sorbitol, used as a sweetener and laxative agent, has been suspected $[23,78]$ of contributing to emesis but two studies failed to show an increase in vomiting in patients receiving $\mathrm{AC}$ plus sorbitol compared to those receiving $\mathrm{AC}$ alone [77, 78]. One study in adults suggested that acupressure may help prevent vomiting [79].

Pulmonary aspiration is the most serious potential complication after AC administration, and cases reported in the medical literature and the TESS have been well summarized by Seger [22]. In some cases, aspiration resulted from accidental insertion of a nasogastric tube into the trachea instead of the stomach $[80,81]$. More commonly, pulmonary aspiration occurs when the drowsy or convulsing patient regurgitated gastric contents, including activated charcoal, into the unprotected airway.

Aspiration of gastric contents can result in acute airway obstruction, bronchospasm, hypoxemia, and pneumonitis, regardless of whether activated charcoal is present. One patient developed a charcoal-containing empyema [10]. Prolonged intubation, death [22], and permanent lung injury [82] may follow.

How common is pulmonary aspiration in overdose patients? In a retrospective study of 4,562 patients admitted to the Hunter Area Toxicology Service (HATS) over a 5-year period, only 71 patients $(1.6 \%)$ were diagnosed with aspiration pneumonia [83]. Significant risk factors for aspiration included depressed mental status, emesis, seizure, ingestion of a tricyclic antidepressant, and a delay of more than $24 \mathrm{~h}$ before admission. However, administration of $\mathrm{AC}$ was not associated with an increased risk of aspiration pneumonitis (odds ratio 1.01, 95\% confidence interval 0.63-1.70). Neither was ingestion of alcohol, benzodiazepines, or antipsychotics. The low overall rate of aspiration in this study is consistent with prospective randomized trials of $\mathrm{AC}$ for acute overdose $[8,63,64]$ and patients receiving $\mathrm{AC}$ alone in other gastric emptying studies [5-7]. The rate of aspiration in patients who are more seriously intoxicated is obviously higher; in the HATS study $11 \%$ of patients admitted to ICU developed aspiration pneumonia [83]. In another study, $45 \%$ of overdose patients admitted to an ICU with a GCS of less than eight points developed aspiration [84]. Endotracheal intubation reduces the risk of aspiration pneumonitis, but not completely: two (4\%) of 50 patients who had been intubated prior to receiving AC still developed aspiration pneumonia [85].

Is charcoal aspiration any different from pulmonary aspiration of gastric contents? In other words, is charcoal staining of lung tissue simply a marker for the presence of gastric acid? In 1988, Menzies reported a fatal case of 
aspiration pneumonia after gastric lavage followed by multiple dose activated charcoal [11]. Necropsy revealed charcoal not only in the alveoli but also within alveolar macrophages and in the sinusoidal histiocytes of the regional lymph nodes. In another case report the following year, a 16-year-old woman developed bronchiolitis obliterans and fatal progressive respiratory failure after charcoal aspiration [12]. Embedded within the bronchiolar scar tissue were large amounts of charcoal associated with a foreign body giant cell reaction. Animal models support the damaging effect of charcoal in the absence of gastric contents: in rats, transtracheal injection of activated charcoal into the lungs caused progressive airway inflammation and obliterative bronchiolitis [86]. And intratracheal instillation of activated charcoal in isolated rat lungs resulted in a significant increase in microvascular permeability compared with sterile water [87]. In an accompanying editorial, Tomaszewski warned of charcoal's "dark side" [88].

\section{What's the Bottom Line on Charcoal?}

We will probably never have all of the evidence we need from prospective randomized controlled trials to definitively guide use of activated charcoal for the overdose patient. There are just too many variables to study: the specific drug or poison; its formulation (liquid, solid, sustained release); when it was ingested, and in what quantity; the clinical condition of the patient; available antidotes or therapeutic agents; and the quality of available emergency medical care. More than a decade after the first publication of the American Academy of Clinical Toxicology (AACT)/European Association of Poison Centres and Clinical Toxicologists (EAPCCT) position statements on gut decontamination, practicing medical toxicologists have differing opinions on how to manage a specific poisoning $[20,89]$. The latest AACT/EAPCCT Position Statement on single dose activated charcoal advises that we not use AC routinely, but does not provide much specific guidance for when it should be considered [16].

Greene proposes the following criteria for oral administration of AC: (1) the ingestion is potentially toxic, (2) there are no contraindications to use of AC, (3) the substance is adsorbed by AC, (4) the substance is likely to still be in the GI tract when $\mathrm{AC}$ is given, (5) the patient is expected to be able to maintain a patent airway or is already intubated, and (6) the GI tract is functionally and anatomically intact; and there is no safer or more effective alternate treatment [23]. Bailey pictures a risk-benefit "gastrointestinal triangle" whose three corners are (1) the hazard posed by the ingestion, (2) the potential benefit of gastrointestinal decontamination, and (3) the risks of the procedure [90,91]. Wiegand designed an algorithm incorporating the risk of aspiration, the potential toxicity of the substance, and the time since ingestion [92]. The algorithm (presented in abstract form but not yet published in full) calls for administration of AC up to $4 \mathrm{~h}$ after ingestion of potentially toxic substances or up to $24 \mathrm{~h}$ in special circumstances: e.g., the drug is probably still present in the stomach (e.g., massive ingestion, anticholinergic, and salicylate); the poisoning could be lethal despite supportive care; a very large ingestion requiring multiple doses of $\mathrm{AC}$ to achieve a 10:1 AC/drug ratio; or ingestion of drug packets ("body packer" or "stuffer"). Wiegand's list of potentially lethal drugs includes cardiotoxic agents such as calcium channel blockers and chloroquine; cytotoxic agents such as amatoxin-containing mushrooms, colchicine, and chemotherapeutic agents; and other menacing poisons such as paraquat.
Table 1 Some contributors to the risk assessment for use of oral activated charcoal

\begin{tabular}{lcc}
\hline & Favors AC & AC risky or not needed \\
\hline Substance & & \\
Low toxicity (e.g., a benzodiazepine) & $\mathrm{X}$ & \\
Highly toxic (e.g., verapamil, colchicine) & $\mathrm{X}$ & $\mathrm{X}$ \\
Modified-release (e.g., bupropion SR) & & \\
Poorly adsorbed by activated charcoal & $\mathrm{X}$ & $\mathrm{X}$ \\
Patient & & $\mathrm{X}$ \\
Alert, cooperative & & \\
Uncooperative, combative & $\mathrm{X}$ & $\mathrm{X}$ \\
Drowsy, not intubated & & $\mathrm{X}$ \\
Airway intact and stable & & \\
Circumstances & & $\mathrm{X}$ \\
Antidote available (e.g., acetaminophen) & $\mathrm{X}$ & \\
Dose taken is small & & \\
Massive ingestion & & \\
Arrives within 1-2 h of ingestion & & \\
\hline
\end{tabular}


What all three of these authors emphasize is the importance of assessing each case individually. Based on personal experience, knowledge of the pharmacology and toxic behavior of a drug, and the unique circumstances of the ingestion, we make our best judgment of the value or risk of GI decontamination. For example, I know that aspirin may remain in the stomach for several hours - in one reported case, gastric lavage recovered over $20 \mathrm{~g}$ of salicylate $9 \mathrm{~h}$ after an ingestion of 200 aspirin tablets (31\% of the ingested dose) [13]. That is the equivalent of over 60 tablets! As a result, I often advise aggressive gut decontamination even several hours after a large aspirin overdose. The same goes for ingestion of a modified-release preparation, especially of a toxic drug such as a calcium channel blocker. On the other hand, given that most overdoses involve nonlethal doses of drugs with low to moderate toxicity, in which GI decontamination is not likely to affect outcome, I am less enthusiastic about routine use of charcoal. The decision to use AC in such cases depends the time since ingestion, the patient's mental status, and their willingness to drink the charcoal, as well as an assessment of the potential toxicity of the ingested drugs. Table 1 illustrates the role of several variables in the decision to use oral activated charcoal.

How to manage the patient who meets some of the "risky" criteria but might still benefit from decontamination? Bailey presents a hypothetical 16-year-old girl who ingested up to 28 venlafaxine SR and 28 zaleplon $45 \mathrm{~min}$ prior to arrival in the ED [92]. She has slurred speech but normal vital signs and a Glasgow Coma Score of 15. This is a case whose discussion among clinical toxicologists is likely to induce heated debate. Bailey contends that the girl may benefit from oral $\mathrm{AC}$ since a significant portion of the venlafaxine probably remains unabsorbed. But there is a risk that the patient will become drowsy or convulse, which would increase the likelihood of pulmonary aspiration. For this reason, many clinicians would favor early endotracheal intubation followed by nasogastric administration of AC. Because the ingested venlafaxine is in a sustained-release preparation, I would also recommend whole bowel irrigation, which may help reduce the total amount absorbed as well as the peak serum level [59].

\section{Summary}

Activated charcoal can effectively bind a wide variety of drugs and poisons with a few notable exceptions (e.g., iron, lithium, potassium, and ethanol). Animal and human volunteer studies, as well as case reports, have shown that $\mathrm{AC}$ can prevent systemic absorption of drugs when given within 1-2 $\mathrm{h}$ of ingestion and perhaps longer after ingestion of sustained-release preparations. The optimal dose is probably a 40:1 ratio (by weight) of charcoal to drug, higher than the conventional 10:1 ratio. Randomized, controlled trials have failed to demonstrate improved clinical outcome in overdose patients treated with $\mathrm{AC}$, and there are risks with its use-most importantly, pulmonary aspiration of gastric contents. But there are important flaws in the RCTs reported to date, and they have not yet cast charcoal into the ash heap of toxicology. I can think of several lines of future inquiry including the use of a higher dose ratio of AC to drug (up to $40: 1$ by weight), the combination of multiple doses of $\mathrm{AC}$ with whole bowel irrigation for massive ingestions, and late decontamination after overdose involving sustained-release drugs. Meanwhile, there is enough evidence from in vitro data, volunteer studies, and case reports to justify the use of oral $\mathrm{AC}$ in selected overdoses.

Open Access This article is distributed under the terms of the Creative Commons Attribution Noncommercial License which permits any noncommercial use, distribution, and reproduction in any medium, provided the original author(s) and source are credited.

\section{References}

1. Rumack BH (1976) Emesis, charcoal and cathartics. JACEP 44(5):44

2. Chin L, Picchioni AL, Gillespie T (1981) Saline cathartics and saline cathartics plus activated charcoal as antidotal treatments. Clin Toxicol 18(7):865-871

3. Dresibach RH (1980) Handbook of poisoning, 10th edn. Lange Medical Publications, Los Altos, pp 24-25

4. Riegel JM, Becker CE (1981) Use of cathartics in toxic ingestions. Ann Emerg Med 10:254-258

5. Kulig K, Bar-Or DCantrill SV, Rosen P, Rumack BH (1985) Management of acutely poisoned patients without gastric emptying. Ann Emerg Med 14:562-567

6. Albertson TE, Derlet RW, Foulke GE, Minguillon MC, Tharratt SR (1989) Superiority of activated charcoal alone compared with ipecac and activated charcoal in the treatment of acute toxic ingestions. Ann Emerg Med 18:56-59

7. Pond SM, Lewis-Driver DJ, Williams GM, Green AC, Stevenson NW (1995) Gastric emptying in acute overdose: a prospective randomized controlled trial. Med J Austr 163(7):345-349

8. Merigian KS, Woodard M, Hedges JR, Roberts JR, Stuebing R, Rashkin MC (1990) Prospective evaluation of gastric emptying in the self-poisoned patient. Am J Emerg Med 8:479-483

9. Pollack MM, Dunbar BS, Holbrook PR, Fields AI (1981) Aspiration of activated charcoal and gastric contents. Ann Emerg Med 10:528-529

10. Justiniani FR, Hippalgaonkar R, Martinez LO (1985) Charcoalcontaining empyema complicating treatment for overdose. Chest 87(3):404-405

11. Menzies DG, Busuttil A, Prescott LF (1988) Fatal pulmonary aspiration of oral activated charcoal. BMJ 297:459-460

12. Elliott CG, Colby TV, Kelly TM, Hicks HG (1989) Charcoal lung. Bronchiolitis obliterans after aspiration of activated charcoal. Chest 96:672-674

13. Matthew H, Mackintosh TF, Tompsett SL, Cameron JC (1966) Gastric aspiration and lavage in acute poisoning. BMJ 1:1333-1337 
14. Harstad E, Moller KO, Simesen MH (1942) U ber den Wert der Magenspu lung bei der Behandlung von akuten Vergiftungen. Acta Med Scand 112:478-514

15. Krenzelok EP, McGuigan M, Lheur P (1997) Position statement: ipecac syrup. American Academy of Clinical Toxicology; European Association of Poisons Centres and Clinical Toxicologists. J Toxicol Clin Toxicol 35(7):699-709

16. Chyka PA, Seger D, Krenzelok EP, Vale JA (2005) American Academy of Clinical Toxicology; European Association of Poisons Centres and Clinical Toxicologists. Position paper: single-dose activated charcoal. Clin Toxicol (Phila) 43(2):61-87

17. American Academy of Clinical Toxicology; European Association of Poisons Centres and Clinical Toxicologists (1999) Position statement and practice guidelines on the use of multi-dose activated charcoal in the treatment of acute poisoning. J Toxicol Clin Toxicol 37(6):731-751

18. Vale JA (1997) Position statement: gastric lavage. American Academy of Clinical Toxicology; European Association of Poisons Centres and Clinical Toxicologists. J Toxicol Clin Toxicol 35(7):711-719

19. Henry JA, Hoffma JR (1998) Continuing controversy on gut decontamination (Commentary). Clin Toxicol 36(7):753-755

20. Hoffman RS (2000) Does consensus equal correctness? (Forum). Clin Toxicol 38(7):689-690

21. Bond JR (2002) The role of activated charcoal and gastric emptying in gastrointestinal decontamination: a state of the art review. Ann Emerg Med 39:273-286

22. Seger D (2004) Single-dose activated charcoal—back up and reassess. Clin Toxicol 42(1):101-110

23. Greene S, Harris C, Singer J (2008) Gastrointestinal decontamination of the poisoned patient. Pediatr Emerg Care 24(3):176-189

24. Cooney DO (1995) Activated charcoal in medical applications. Marcel Dekker, New York

25. Cooney DO (1995) Activated charcoal in medical applications. Marcel Dekker, New York, p 25

26. Cooney DO (1977) A "superactivated" charcoal for antidotal use in poisonings. Clin Toxicol 11(4):387-390

27. Cooney DO (1995) Activated charcoal in medical applications. Marcel Dekker, New York, p 29

28. Cooney DO (1995) Activated charcoal in medical applications. Marcel Dekker, New York, p 31

29. Cooney DO (1995) Activated charcoal in medical applications. Marcel Dekker, New York, p 186

30. Cooney DO (1995) Activated charcoal in medical applications. Marcel Dekker, New York, p 214

31. Chin L, Picchioni AL, Bourn WM, Laird HE (1973) Optimal antidotal dose of activated charcoal. Toxicol Appl Pharmacol 26:103-108

32. Jurgens C, Groth Hoegberg LC, Graudal NA (2009) The effect of activated charcoal on drug exposure in healthy volunteers: a metaanalysis. Clin Pharmacol Ther 85(5):501-505

33. Decker WJ, Combs HF, Corby DG (1968) Adsorption of drugs and poisons by activated charcoal. Toxicol Appl Pharmacol 13:454-460

34. Favin FD, Klein-Schwartz W, Oderda GM, Rose SR (1988) In vitro study of lithium carbonate adsorption by activated charcoal. Clin Toxicol 26(7):443-450

35. Cooney DO (1995) Activated charcoal in medical applications. Marcel Dekker, New York, p 11

36. Cooney DO (1995) Activated charcoal in medical applications. Marcel Dekker, New York, p 440

37. Cooney DO (1995) Activated charcoal in medical applications. Marcel Dekker, New York, p 235

38. Decker WJ, Corby DG, Hilburn RE, Lynch RE (1981) Adsorption of solvents by activated charcoal, polymers and mineral sorbents. Vet Hum Toxicol 23(Suppl 1):44-46
39. Cooney DO (1995) Activated charcoal in medical applications. Marcel Dekker, New York, pp 197-294

40. Curtis RA, Barone J, Giacona N (1984) Efficacy of ipecac and activated charcoal/cathartic. Prevention of salicylate absorption in a simulated overdose. Arch Int Med 144:48-52

41. Tenenbein M, Cohen S, Sitar DS (1987) Efficacy of ipecacinduced emesis, orogastric lavage, and activated charcoal for acute overdose. Ann Emerg Med 16:838-841

42. Yeates PJA, Thomas SHL (2000) Effectiveness of delayed activated charcoal administration in simulated paracetamol (acetaminophen) overdose. Br J Clin Pharmacol 49:11-14

43. Green R, Grierson R, Sitar DS, Tenenbein M (2001) How long after drug ingestion is activated charcoal still effective? Clin Toxicol 39(6):601-605

44. Green R, Sitar DS, Tenenbein M (2004) Effect of anticholinergic drugs on the efficacy of activated charcoal. J Toxicol Clin Toxicol 42(3):267-272

45. Mullins M, Froelke BR, Rivera MR (2009) Effect of delayed activated charcoal on acetaminophen concentration after simulated overdose of oxycodone and acetaminophen. Clin Toxicol 47:112-115

46. Kirshenbaum LA, Matthews SC, Sitar DS, Tenenbein M (1989) Whole-bowel irrigation versus activated charcoal in sorbitol for the ingestion of modified-release pharmaceuticals. Clin Pharmacol Ther 46(3):264-271

47. Laine K, Kivisto KT, Neuvonen PJ (1997) Effect of delayed administration of activated charcoal on the absorption of conventional and slow-release verapamil. Clin Toxicol 35(3):263-268

48. Minton NA, Henry JA (1995) Prevention of drug absorption in simulated theophylline overdose. Clin Toxicol 33(1):43-49

49. Comstock EG, Boisaubin EV, Comstock BS, Faulkner TP (1982) Assessment of the efficacy of activate charcoal, following gastric lavage in acute drug emergencies. J Toxicol Clin Toxicol 19 (2):149-165

50. Hulten BA, Adams R, Askenasi R, Dallos V, Dawling S (1988) Activated charcoal in acute tricyclic antidepressant poisoning. Hum Exp Toxicol 7:307-310

51. Underhill TJ, Greene MK, Dove AF (1990) A comparison of the efficacy of gastric lavage, ipecacuanha and activated charcoal in the emergency management of paracetamol overdose. Arch Emerg Med 7:148-154

52. Buckley NA, Whyte IM, O'Connell DL, Dawson AH (1999) Activated charcoal reduces the need for $\mathrm{N}$-acetylcysteine treatment after acetaminophen (paracetamol) overdose. Clin Toxicol 37 (6): $753-757$

53. Spiller HA, Winter ML, Klein-Schwartz W, Bangh SA (2006) Efficacy of activated charcoal when administered more than four hours after acetaminophen overdosed. J Emerg Med 30(1):1-5

54. Spiller HA, Sawyer TS (2007) Impact of activated charcoal after acute acetaminophen overdoses treated with $\mathrm{N}$-acetylcysteine. J Emerg Med 33(2):141-144

55. Friberg LE, Isbister GK, Duffull SB (2006) Pharmacokineticpharmacodynamic modelling of QT interval prolongation following citalopram overdoses. Br J Clin Pharmacol 61(2):177-190

56. Isbister GK, Friberg LE, Stokes B, Buckley NA, Lee C, Gunja N, Brown SG, Macdonald E, Graudins A, Holdgate A, Duffull SB (2007) Activated charcoal decreases the risk of QT prolongation after citalopram overdose. Ann Emerg Med 50:593-600

57. Friberg LE, Isbister GK, Hackett LP, Duffill SB (2005) The population pharmacokinetics of citalopram after deliberate selfpoisoning: a Bayesian approach. J Pharmacokinet Pharmacodyn 32:571-605

58. Isbister GK, Friberg LE, Hackett LP, Duffill SB (2007) Pharmacokinetics of quetiapine in overdose and the effect of activated charcoal. Clin Pharmacol Ther 81:821-827

59. Kumar VVP, Oscarsson S, Friberg LE, Isbister GK, Hackett LP, Duffill SB (2009) The effect of decontamination procedures on 
the pharmacokinetics of venlafaxine in overdose. Clin Pharmacol Ther 86(4):403-410

60. Roberts DM, Southcott E, Potter JM, Roberts MS, Eddleston M, Buckley NA (2006) Pharmacokinetics of digoxin cross-reacting substances in patients with acute yellow oleander (Thevetia peruviana) poisoning, including the effect of activated charcoal. Ther Drug Monit 28(6):784-792

61. de Silva HA, Fonseka MMD, Pathmeswaran A, Alahakone DGS, Ratnatilake GA, Gunatilake SB, Ranasinha CD, Lalloo DG, Aronson JK, de Silva HJ (2003) Multiple-dose activated charcoal for treatment of yellow oleander poisoning: a single-blind, randomised, placebo-controlled trial. Lancet 361:1935-1938

62. Eddleston M, Juszczak E, Buckley NA, Senarathna L, Mohamed F, Dissanayake W, Hittarage A, Azher S, Jeganathan K, Jayamanne S, Sheriff MHR, Warrell DA (2008) Mutliple-dose activated charcoal in acute self-poisoning: a randomised controlled trial. Lancet 371:579-587

63. Merigian KS, Blaho KE (2002) Single-dose oral activated charcoal in the treatment of the self-poisoned patient: a prospective, randomized, controlled trial. Am J Ther 9:301-308

64. Cooper GM, Le Couteur DG, Richardson D, Buckley NA (2005) A randomized clinical trial of activated charcoal for the routine management of oral drug overdose. QJ Med 98:655-660

65. Eddleston M, Haggalla S, Reginald K, Sudarshan K, Senthilkumaran M, Karalliedde L, Ariaratnam A, Sheriff MHR, Warrall DA, Buckley NA (2007) The hazards of gastric lavage for intentional self-poisoning in a resource poor location. Clin Toxicol 45(2): 136-143

66. Gomez HF, Brent JA, Munoz DC, Mimmack RF, Ritvo J, Phillips S, McKinney P (1994) Charcoal stercolith with intestinal perforation in a patient treated for amitriptyline ingestion. $\mathrm{J}$ Emerg Med 12(1):57-60

67. Erolgu AH, Kucuktulu U, Erciyes N, Turgutalp H (2002) Multiple dose activated charcoal as a cause of acute appendicitis. J Toxicol Clin Toxicol 41(1):71-73

68. Green JP, McCauley W (2006) Bowel perforation after single-dose activated charcoal. Can J Emerg Med 8(5):358-360

69. Vilska J (1989) Indications and contraindications of activated charcoal in a poison control center. The viewpoint of the Poison Control Center of Finland. J Toxicol Clin Exp 9(4):295-298

70. Spiller HA, Rodgers GC (2001) Evaluation of administration of activated charcoal in the home. Pediatrics 108(6):E100

71. Kornberg AE, Dolgin J (1991) Pediatric ingestions: charcoal alone versus ipecac and charcoal. Ann Emerg Med 20:648-651

72. Osterhoudt KC, Alpern ER, Durbin D, Nadel F, Henretig FM (2004) Activated charcoal administration in a pediatric emergency department. Pediatr Emerg Care 20(8):493-498

73. Guenther Skokan E, Junkins EP, Corneli HM, Schunk JE (2001) Taste test: children rate flavoring agents used with activated charcoal. Arch Pediatr Adolesc Med 155:683-686

74. Dagnone D, Matsui D, Rieder MJ (2002) Assessment of the palatability of vehicles for activated charcoal in pediatric volunteers. Pediatr Emerg Care 18(1):19-21
75. Cheng A, Ratnapalan S (2007) Improving the palatability of activated charcoal in pediatric patients. Pediatr Emerg Care 23 (6):384-386

76. Boyd R, Hanson J (1999) Prospectuve single blinded randomised controlled trial of two orally administered activated charcoal preparations. J Accid Emerg Med 16:24-25

77. Minocha A, Wiley SH, Chabbra DR, Harper CR, Spyker DA (1986) Superior efficacy of sorbitol cathartics in poisoned patients [abstract]. Vet Hum Toxicol 5:494

78. Osterhoudt KC, Durbin D, Alpern ER, Henretig FM (2004) Risk factors for emesis after therapeutic use of activated charcoal in acutely poisoned children. Pediatrics 113:806-810

79. Eizember FL, Tomaszewski CA, Kerns WP (2002) Acupressure for prevention of emesis in patients receiving activated charcoal. J Toxicol Clin Toxicol 40(6):775-780

80. Harris CR, Filandrinos D (1993) Accidental administration of activated charcoal into the lung: aspiration by proxy. Ann Emerg Med 22:1470-1473

81. Sabga E, Dick A, Lertzman M, Tenenbein M (1997) Direct administration of charcoal into the lung and pleural cavity. Ann Emerg Med 30:695-697

82. Graff GR, Stark J, Berkenbosch JW, Holcomb GW, Garola RE (2002) Chronic lung disease after activated charcoal aspiration. Pediatrics 109:959-961

83. Isbister GK, Downes F, Sibbritt D, Dawson AH, Whyte IM (2004) Aspiration pneumonitis in an overdose population: frequency, predictors, and outcomes. Crit Care Med 32(1):88-93

84. Adnet F, Baud F (1996) Relation between Glasgow Coma Scale and aspiration pneumonia. Lancet 348(9020):123-124

85. Moll K, Kerns W 2nd, Tomaszewski C, Rose R (1999) Incidence of aspiration pneumonia in intubated patients receiving activated charcoal. J Emerg Med 17(2):279-283

86. Lee AG, Wagner FM, Chen MF, Serrick C, Giaid C, Shennib H (1998) A novel charcoal-induced model of obliterative bronchiolitis-like lesions: implications of chronic nonspecific airway inflammation in the development of posttransplantation obliterative bronchiolitis. J Thorac Cardiovasc Surg 115(4):822-827

87. Arnold TC, Willis BH, Xiao F, Conrad SA, Carden DL (1999) Aspiration of activated charcoal elicits an increase in lung microvascular permeability. Clin Toxicol 37(1):9-16

88. Tomaszewski CA (1999) Activated charcoal-treatment or toxin? (Commentary). Clin Toxicol 37(1):17-18

89. Juurlink DN, McGuigan MA (2000) Gastrointestinal decontamination for enteric-coated aspirin overdose: what to do depends on who you ask. Clin Toxicol 38(5):465-470

90. Bailey B (2005) Gastrointestinal decontamination triangle (letter). Clin Toxicol 1:59-60

91. Bailey B (2008) To decontaminate or not to decontaminate? The balance between potential risks and forseeable benefits. Clin Pediatr Emerg Med 9:17-23

92. Wiegand $\mathrm{TJ}, \mathrm{Wu}$ L, Dempsey DA (2005) Algorithm for activated charcoal (AC) use for ingestions [abstract]. Clin Toxicol 43 (6):673 